\title{
Yellow bristle grass: a recent weed incursion in Waikato dairy pastures
}

\author{
T.K. JAMES, K.N. TOZER and A.RAHMAN \\ AgResearch, Ruakura Research Centre, Hamilton, New Zealand \\ trevor.james@agresearch.co.nz
}

\begin{abstract}
Yellow bristle grass (Setaria pumila) is a summer growing annual grass with a $\mathrm{C}_{4}$ photosynthetic pathway. It is now becoming a serious weed in pasture where it is highly competitive with perennial ryegrass (Lolium perenne)/white clover (Trifolium repens) and is avoided by stock when at the seed head stage. On severely infested farms, it is estimated to cause production losses in the order of $\$ 100000 / 100$ ha unit, mostly due to stock not grazing areas where the yellow bristle grass is seeding. First recorded in the early $20^{\text {th }}$ century, yellow bristle grass was a plant of minor significance until very recently. In the past 10 years several farming practices such as stocking rate, post-grazing residual and grazing rotation, have changed which could explain why it has become a problem weed. Selective herbicidal control in pasture is probably not a viable solution, so pasture renovation with intercropping and improved management methods are currently being evaluated.
\end{abstract}

Keywords: yellow bristle grass, Setaria pumila, pasture, grass weed

\section{Introduction}

Yellow bristle grass (Setaria pumila (Poir.) Roem. Et Schult, previously listed as S. glauca and S. lutescens) was first recorded in New Zealand in 1905 (Allan 1940; Cheeseman 1925; Anonymous 2009). Farmers and graziers brought their own crop and pasture seeds and yellow bristle grass is likely to have been introduced as a contaminant of grass seed along with other weeds such as ragwort (Jacobaea vulgaris) and Californian thistle (Cirsium arvense). However, unlike many other introductions such as ragwort and nodding thistle (Carduus nutans) it did not immediately become a problem.

Hilgendorf (1918) discusses 18 grass weeds of pasture including barley grass (Critesion $s p$.), sweet vernal (Anthoxanthum odoratum), soft brome (Bromus hordeaceus) annual poa (Poa апnиa) and rats tail (Sporobolus africanus), but does not mention any of the bristle grasses (Setaria sp.). There is only brief mention in the literature (e.g. Hilgendorf 1926 - 1960) of yellow bristle grass being a weed in maize (Zea mays), turnip (Brassica rapa) and mangels (Beta vulgaris) land in the Auckland district in late summer. It was not observed as a problem weed in pasture until the early twenty first century, more than 100 years after its introduction. This is possibly due to its limited early distribution and the fact that all the early herbarium samples were collected only from the Auckland district. There is no record of its further spread until 1991 and 1995 when specimens were collected from Nelson and Taranaki districts, respectively (Anonymous 2009). Currently, yellow bristle grass has been found in all regions of the North Island and in Nelson and Marlborough in the South Island. In 2007, the Yellow Bristle Grass Action Group was established by a group of farmers in Waikato who were concerned about the spread of this weed and the negative impact it was having on their pastures (James 2008).

Yellow bristle grass is believed to have originated in Southern Europe but its route to New Zealand is unclear as it is naturalised in many temperate countries (Edgar \& Connor 2000; Panday \& Singh 1992). Yellow bristle grass is common in temperate and drier places in Eastern and Southern Europe, North Africa, Asia, North America and Australia where it is usually described as an annual grass that provides an alternative source of forage during summer (Dekker 2003). In these situations it is not regarded as a weed although it has been observed to cause physical damage to the mouth and tongue of grazing stock when in the seed head stage (Fava et al. 2000). In New Zealand, there is usually a surplus of alternative forage, which may be why stock learns to avoid grazing yellow bristle grass when the seed head is present. This leads to poor grazing patterns within pastures and overall loss of productivity (James 2008).

This paper documents the emergence of a new problem weed of pasture and reports on research being carried out to assist farmers in managing yellow bristle grass.

\section{Biology}

Yellow bristle grass is a tufted, multi-tillered upright annual that grows $25-45 \mathrm{~cm}$ high. It has a flattened leaf sheath, often red or purple at the base. Leaves are flat, soft and hairless except for a few long hairs at the base. Germination is normally from mid November to February when soil temperatures are greater than $20^{\circ} \mathrm{C}$ in the surface layer from which the seed germinates (Steinmaus et al. 2000). It has a $C_{4}$ photosynthetic pathway which enables it to grow rapidly in the warmer summer months 
and normally commences flowering 6-8 weeks after emergence (Dekker 2003). This means that if conditions are right for growth, the seed heads begin to appear at the end of December when day length begins to decrease, although it has been observed to commence flowering up to 2 months earlier in warm dry environments such as gravel raceways and embankments. The seed head is characterised by seven to ten bristles emerging from below each floret. Initially green, the bristles soon turn yellow, giving rise to its common name. Yellow bristle grass is a prolific seed producer. Plants are able to produce 50-100 or more seed heads, each containing 60200 seeds when allowed to grow without grazing (T.K. James unpublished data). The seeds shatter at maturity leaving the bristles attached to the fruiting stem and this may remain on the plant until May or June. The fallen seeds create a seedbank in the soil which is critical to the plant survival. Normally, soft- coated seed such as those of yellow bristle grass only survive in the soil for 1 or 2 years (Masin et al. 2006) so seed production is critical to its continued existence as the plant is frost tender and dies over winter.

Along with several other summer growing grasses such as summer grass (Digitaria sanguinalis) and smooth witchgrass (Panicum dichotomiflorum), this plant has the ability to rapidly colonise and fill gaps in pasture during late spring and early summer (Wardle et al. 1994). The gaps might result from physical damage such as pugging, wheel tracks and feed-out lines, or from gaps that appear when winter growing weeds such as hedge mustard (Sisymbrium officinale), shepherd's purse (Capsella bursa-pastoris), hairy buttercup (Ranunculus sardous) and annual poa (Poa annua) die out. Although its $\mathrm{C}_{4}$ pathway makes it an efficient user of water and it is partially drought tolerant, it still requires moist conditions to germinate and grows best in regions with annual rainfall exceeding $500 \mathrm{~mm}$ or in areas of increased soil moisture such as ephemeral drains (Dekker 2003).

The bristles of all Setaria sp. are barbed but for most species, including yellow bristle grass, the barbs face upwards, away from the seed, which means they do not readily hook onto objects. This, in combination with the seed readily separating from the bristles indicates that the barbs are not present to provide a means of seed dispersal. Rather their role appears to be a deterrent to grazing. The bristles from yellow bristle grass have been reported to cause mouth ulcers in grazing cattle (Fava et al. 2000). Yellow bristle grass can outgrow perennial ryegrass during the warm summer months and as the grazing stock learn to avoid it when seed heads begin to appear, clumps of this weed soon become visible in pastures and, unless topped, tend to remain for the rest of the summer.

\section{The problem}

Like many other weedy summer growing grasses such as summer grass, crowfoot grass (Eleusine indica) and barnyard grass (Echinochloa crus-galli), yellow bristle grass is of poor nutritive value (Marten \& Andersen 1975; Nashiki et al. 2005; Sultan et al. 2007; Tozer \& Cameron 2009) and when combined with stock avoidance, its presence can lead to serious problems in pastures. Overall dry matter consumed from the pasture is reduced and areas of the sward free of the weed tend to be overgrazed to compensate. Evidence from affected farmers shows that even light infestations ( $0-10 \%$ cover) of yellow bristle grass can reduce farm production by $5-10 \%$ and that superior sharemilkers and managers do not like to work on infested properties. On severely infested Waikato farms (members of the Yellow Bristle Grass Action Group), losses could be as high as $\$ 100$ 000/100 ha unit (T.K. James unpublished data).

It is difficult to ascertain why, after being present for so many years, yellow bristle grass has only recently been classified by Waikato farmers as highly invasive being capable of covering $20-40 \%$ of ground within 5 years of entering the pasture. During the last 5-10 years many farming and district practices have changed and any one or a combination of these could have led to the current problem. The simplest explanation could be that suddenly, something within this weed changed (e.g. a particular combination of genes came to dominate the population as a result of some environmental pressure) which allowed it to spread and move into pasture. This is unlikely, however, as it would still need a mechanism for spread, so other explanations may be more plausible. An important one appears to be the decline in the use of residual herbicides for controlling weeds on roadsides. This has allowed a proliferation of annual weeds and those conditions appeared to have suited yellow bristle grass. In the last 10 years growth of yellow bristle grass along roadways has been observed by farmers to have become more common and more abundant. From here it is but a short step into pasture. The plant can fall or be blown through the fence, carried by vehicles or stock or moved when hay is made from a roadside source. Once established in pasture the soil seedbank quickly builds up and the plant becomes persistent. In autumn 2006, soil cores (20 cores each $25 \mathrm{~mm}$ diameter by $100 \mathrm{~mm}$ deep, taken from paddocks that the farmer estimated to have either a light, medium or heavy infestation revealed 5,000-10,000 yellow bristle grass seeds $/ \mathrm{m}^{2}$ in the lightly infested pasture and more than 20,000 seeds/ $\mathrm{m}^{2}$ in heavily infested pasture (James 2008). Other contributing factors could be stocking rates which have increased over the last 10 years; pasture management practices which have lead to reduced post-grazing pasture residuals; reduced ryegrass persistence and 
increased use of maize for silage and green feed in the dairy sector. A botanical survey of Waikato dairy pastures showed more yellow bristle grass was present where there was lower post-grazing residual dry matter, lower soil $\mathrm{pH}$ and lower Olsen P levels (Tozer et al. 2008). This infers that vigorous, fertile pastures will help to prevent the ingress and spread of this weed, but further research is required.

\section{The solution?}

As with all annual species, control can be achieved by breaking the reproductive cycle. However, where there is a store of seed in the soil, this needs to be depleted at the same time. An obvious way to break the cycle is to kill the weed with herbicides. However, selectively removing a grass weed from within a grass dominated pasture is not simple, and there are few herbicides available to do this. In trials carried out over 2 years, James \& Rahman (2009) found that the best control which could be achieved from a single herbicide application was $70 \%$ by 2,2-DPA (Dalapon, $2 \mathrm{~kg}$ product/ha) alone or in combination with either TCA (Teedal, $7 \mathrm{~kg}$ product/ha) or carbetamide (Teedal Gold, $3 \mathrm{~kg}$ product/ha), applied in December. Further, seed head counts from the herbicide treated plots showed that there was likely to be sufficient seed to replenish the soil seedbank. While repeat applications may be more effective, the level of pasture damage incurred is also likely to be high.

With herbicides being an expensive and possibly impractical solution, farmers need to turn to cultural and managerial solutions. Topping and silage making have some potential as initial tests involving bagged seed ( 5 replicate bags with 200 seed in each bag) placed in the centre and at the side of grass silage stacks as they are being made or in wrapped bales immediately after they were made, have shown that yellow bristle grass seed does not germinate after 3 months of ensiling (T. K. James unpublished data). However, topping does not kill the plant and it will still produce seed albeit fewer in number and usually on a shorter stem which makes repeat topping more difficult.

As yellow bristle grass is entirely dependent on seed to maintain its life cycle, the long term solution to managing this weed will most likely be found in developing more competitive pastures and minimising its germination or incursion by better farm practices that do not open up the pastures at critical times (Tozer et al. 2008). To this end, pasture renovation has to be a critical step. Correctly done, pasture renovation can not only create a more competitive sward, it can also be used to severely deplete the soil seedbank. The latter is achieved by using an intercrop rotation within which yellow bristle grass can be controlled for a season or two and so reduce or eliminate soil seedbank replenishment. Annual crops such as turnips and maize or biennial crops such as chicory (Cichorium intybus) would be suitable choices as there are herbicides available for control of yellow bristle grass in these crops. With the soil seedbank depleted, new pasture can be established without the immediate threat of reinvasion from within. It is then a matter of choosing management practices which minimise introduction of seed, such as not grazing cows on new pasture after grazing an infested pasture (as yellow bristle grass seed is able to survive passage through the rumen, as demonstrated when fresh manure was mixed 50:50 with sterile potting mix and yellow bristle grass plants emerged soon after) or feeding out infested hay on new pasture. Pasture renovation demonstration trials are currently underway to evaluate different renovation options such as intercrop type and post-renovation pasture management.

\section{Conclusion}

There do not appear to be any easy answers for management of yellow bristle grass. With the trials currently underway and ongoing support from many farmers it is hoped that those farm practices that contribute to the problem of yellow bristle grass infestation and spread will be identified. This will allow farmers who wish to better manage yellow bristle grass to stop its spread or successfully control it, to do so. Like many similar problems the managerial answers are also likely to come from farmers themselves with key inputs from researchers in critical areas of science.

\section{ACKNOWLEDGEMENTS}

Thanks are due to the Yellow Bristle Grass Action group for support and funding of the survey, and MAF Sustainable Farming Fund for funding the pasture renovation demonstration trials.

\section{REFERENCES}

Allan, H.H. 1940. A handbook of the naturalised flora of New Zealand. Department of Scientific and Industrial Research Bulletin No. 83. E. V. Paul Government Printer, Wellington. 344 pp.

Anonymous, 2009. Landcare Research New Zealand plant search. http://nzflora.landcareresearch.co.nz/default.asp $\mathrm{x}$ ?NavControl=search\&selected $=$ NameSearch.

Cheeseman, T.F. 1925. Manual of the New Zealand flora. W.A.G. Skinner, Government Printer, Wellington. $1164 \mathrm{pp}$.

Dekker, J. 2003. The foxtail (Setaria) species-group. Weed Science 51: 641-656.

Edgar, E.; Conner, H.E. 2000. Flora of New Zealand Volume V. Manaaki Whenua Press, Lincoln, New Zealand. $650 \mathrm{pp}$. 
Fava, E.; Rossi, F.; Speranzini, G.; Nigrelli, A.; Rossignoli, G.; Gelmetti, D.; Mariotti, M.G.; Sali, G.; Stöber, M.; Wolf, P.; Von Boberfeld, O. 2000. Enzootic ulcer in the back of the tongue in cattle after ingestion of hay containing flower clusters of yellow bristle-grass. Deutsche Tierarztliche Wochenschrift 107(9): 351-354.

Hilgendorf, F.W. 1918. Pasture plants and pastures of New Zealand. Whitcombe \& Tombs Limited, Auckland. 96 pp.

Hilgendorf, F.W. 1926, 1937, 1942, 1948, 1952, 1960. Weeds of New Zealand and how to eradicate them. Whitcombe \& Tombs Limited, Christchurch. 260 pp.

James, T.K. 2008. Yellow bristle grass - the ute guide. Ministry of Agriculture and Forestry, Wellington, New Zealand. 28 pp.

James, T.K.; Rahman, A. 2009. Selective chemical control of yellow bristle grass (Setaria pumila) in pasture. New Zealand Plant Protection 62 (in press).

Marten, G.C.; Andersen, R.N. 1975. Forage nutritive value and palatability of 12 common annual weeds. Crop Science 15: 821-827.

Masin, R.; Zuin, M,C.; Otto, S.; Zanin, G. 2006 Seed longevity and dormancy of four summer annual grass weeds in turf. Weed Research 46: 362-370.
Nashiki, M.; Narita, H.; Higashayama, Y. 2005. Herbage mass, nutritive value and palatability of five grass weeds for cattle in northern Tohoku region in Japan. Weed Biology and Management 5: 110-117.

Panday, C.B.; Singh, J.S. 1992. Influence of rainfall and grazing on herbage dynamics in a seasonally dry tropical savanna. Plant Ecology 102: 101-124.

Steinmaus, S.J.; Prather, T.S.; Holt, J.S. 2000. Estimation of base temperatures for nine weed species. Journal of Experimental Botany 51: 275-286.

Sultan, J.I.; Rahim, I.; Nawaz, H.; Yaqoob, M. 2007. Nutritive value of marginal land grasses of northern grasslands of Pakistan. Pakistan Journal of Botany 39: 1071-1082.

Tozer K.N.; Cameron C.A. 2009. Sweet success? Managing yellow bristle grass (Setaria pumila) with grazing attractants in dairy pasture. Proceedings of the New Zealand Grassland Association 71: 43-47.

Tozer, K.N.; James T.K.; Cameron C.A. 2008. Environmental and management factors associated with Setaria pumila: implications for pasture management. New Zealand Plant Protection 61: 121-126.

Wardle, D.A.; Barker, G.M.; Nicholson, K.S.; Addison, P.J. 1994. Cyclic oscillations between summerannual $\left(\mathrm{C}_{4}\right)$ and winter-annual weed grass in Waikato dairy pastures. Proceedings of the New Zealand Plant Protection Conference 47: 34-37. 